http://journal.uin-alauddin.ac.id/index.php/lamaisyir

\title{
THE APPLICATION OF UTAUT MODEL TO THE CROWDFUNDING BASED HALAL TOURISM CAPITAL PLATFORM INNOVATION
}

\author{
Ricky Dendi Oktavian' ${ }^{1}$ dan M. Ruslianor Maika² \\ 1,2Universitas Muhammadiyah Sidoarjo \\ Jl. Mojopahit No.666 B, Sidowayah, Celep, Sidoarjo, Indonesia \\ rickydendi87@gmail.com ${ }^{1}$, mr.maika@umsida.ac.id ${ }^{2}$
}

Received: 29 September 2020; Revised: 25 November 2020; Published: 04 Desember 2020

\begin{abstract}
ABSTRAK
Permasalahan tentang minimnya aggaran dalam pengembanggan pariwisata halal di Indonesia mendorong peneliti untuk mencari solusi yang inovatif. Penelitian ini bertujuan untuk mengetahui pandangan para responden tentang rencana pembangunan platform permodalan pariwisata halal. Penelitian ini menggunakan metode kualitatif dengan menerapkan pendekatan fenomonologi sebagai upaya menggali informasi dari responden berdasarkan pengalamannya. Hasil penelitian ini terbagi menjadi empat kategori yaitu perfomance expectancy, effort expectancy, social influence, dan facilitating conditions yang disajikan dalam bentuk network untuk menggabungkan setiap jawaban pada masing-masing kategori. Kesimpulan yang diperoleh dari penelitian ini adalah pada kategori perfomance expectancy responden menyetujui adanya inovasi platform permodalan pariwisata halal, kemudian responden merasakan kemudahan dengan adanya inovasi platform permodalan pariwisata halal pada kategori effort expectancy. Pada kategori social influence responden menyatakan ketertarikan dan minatnya dalam menggunakan inovasi platform permodalan pariwisata halal, dengan memberikan saran perbaikan infrastruktur dan fasilitas yang menunjang inovasi platform permodalan pariwisata halal yang termuat dalam kategori facilitating conditions.
\end{abstract}

Kata kunci : Permodalan; Pariwisata Halal; Crowdfunding.

\section{ABSTRACT}

The lack of budget in developing halal tourism in Indonesia encourages researchers to find innovative solutions. This study aims to determine respondents' views on the plan to build a halal tourism capital platform. This study used a qualitative method by applying a phenomenological approach to gather information from respondents based on their experiences. This study's results are divided into four categories, namely performance expectancy, effort expectancy, social influence, and facilitating conditions presented in the form of a network to combine each answer in each category. The conclusion obtained from this study is that in the variety of performance expectations, the respondents agreed on the halal tourism capital platform's innovation. The respondents felt the ease with the halal tourism capital platform's design in the effort expectancy category. In the social influence category, respondents expressed their interest and interest in using the halal tourism capital platform's innovation by providing suggestions for improving infrastructure and facilities that support the halal tourism capital platform's invention in the facilitating conditions category.

Keywords : Capital; halal tourism; crowdfunding 


\section{PENDAHULUAN}

Perkembangan teknologi mendorong berbagai macam sektor kehidupan untuk terus berkembang ke arah digitalisasi. Sektor ekonomi menjadi salah satu yang terkena dampak digitalisasi, buktinya adalah kemunculan financial technology (fintech) yang semakin marak. Data Otoritas Jasa Keuangan pada bulan oktober 2019 mengenai jumlah financial technology (fintech) di Indonesia menyatakan ada 144 fintech yang terdaftar dan memiliki izin untuk beroperasi(OJK, 2019). Kemunculan fintech dimanfaatkan oleh perbankan sebagai strategi untuk memperluas jangkauan dan menciptakan layanan baru dengan cara bertranformasi menjadi bentuk fintech(Marginingsih, 2019). Dampak yang terjadi akibat dari kemunculan fintech adalah terbentuknya sebuah ekosistem baru keuangan dan perbankan yang berbasis teknologi(Ansori, 2019).

Crowdfunding menjadi salah satu segmen industri keuangan yang mengalami pertumbuhan paling pesat, dan menjadi bentuk utama sebuah fintech. Pada umumnya pendanaan crowdfunding berbentuk sumbangan (proyek filantropis) maupun pembiayaan langsung (utang dan ekuitas). Pemanfaatan sistem crowdfunding dalam sebuah fintech dapat meningkatkan efisiensi kinerja lembaga keuangan dalam upaya mencapai target perusahaan. Saat ini produk berbasis islamic atau berlabel halal menjadi populer, contohnya ialah munculnya sistem crowdfunding yang berbasis syariah yaitu islamic crowdfunding(Hoque et al., 2018).

Islamic Crowdfunding dalam aktivitasnya bekerjasama dengan kapital boost sebagai pihak perantara, kapital boost menjadi perusahaan startup yang memiliki tugas melakukan pengawasan terhadap aktivitas bisnis UMK untuk mencegah penyalahgunaan dana yang telah diberikan. Kapital boost selaku perusahaan crowdfunding menawarkan beberapa macam bentuk pendanaan seperti pembelian aset dan piutang(Hendratmi et al., 2019).

Pariwisata halal di Indonesia memiliki potensi yang besar, menurut data Global Muslim Travel Index pada tahun 2018 Indonesia menempati posisi kedua dibawah Malaysia sebagai negara tujuan pariwisata halal (Crescent Rating, 2018). Pada kenyataanya pariwisata halal di Indonesia sebenarnya masih sangat minim dan hanya berkembang di 10 provinsi saja, sehingga perlu adanya pengembangan pariwisata halal(IMTI, 2018). Pemerintah saat ini tengah fokus untuk melakukan pengembangan terhadap pariwisata halal dengan memberikan anggaran dana sebagai modal dalam mengembangkan pariwisata halal, namun anggaran dana yang diberikan dirasa masih kurang (Zuhro, 2019).

Melalui inovasi platform permodalan bagi pariwisata halal ini diharapkan dapat membantu dalam upaya pengembangan pariwisata halal di Indonesia. Penilaian sejauh mana platform permodalan pariwisata halal ini dapat diterima oleh masyarakat, maka perlu dilakukan analisis yang lebih mendalam dengan 
menggunakan teori terpadu penerimaan dan penggunaan teknologi atau UTAUT (Unified Theory of Acceptance and Use of Technology).

\section{Halal Tourism}

Halal tourism adalah salah satu bagian dari industri pariwisata, dimana pelayanan yang diberikan dijalankan sesuai dengan hukum islam serta diperuntukan bagi wisatawan muslim yang semakin meningkat jumlahnya setiap tahun(Jaelani, 2017). Pariwisata halal menjadi pilihan alternatif bagi para wisatawan muslim maupun non-muslim di seluruh dunia.

Predikat sebagai negara dengan jumlah penduduk muslim terbesar di dunia, membuat Indonesia memiliki potensi besar untuk mengembangkan pariwisata halal(Indonesia.go.id, 2019). Pada proses pengembangan industri pariwisata halal diperlukan fasilitas dan infrastruktur yang memadai agar dapat menunjang kebutuhan wisatawan muslim, sehingga potensi besar pariwisata halal di Indonesia yang tersebar di berbagai daerah dapat dikembangkan dengan maksimal dan memberikan keuntungan kepada semua pihak (Adinugraha et al, 2018).

\section{Fintech Shariah}

Financial technology (fintech) merupakan sebuah inovasi baru dalam sistem pelayanan keuangan dengan memanfaatkan teknologi untuk menciptakan produkproduk layanan seperti aplikasi proses yang langsung terhubung dengan penyedia jasa layanan keuangan (Rahmawati et al., 2020). Financial technology (fintech) terus mengalami perkembangan setiap tahunya, hingga muncul sebuah skema baru dalam penawaran sebuah fintech yaitu fintech syariah.

Fintech syariah merupakan sebuah inovasi baru dalam sistem pelayanan keuangan yang dijalankan atas dasar hukum islam dengan memanfaatkan kemajuan teknologi. Fintech syariah memberikan skema dan penawaran yang berbeda dengan layanan konvensional, serta menetapkan penggunaan dana hanya untuk bisnis yang halal saja (Wahyuni, 2019). Fatwa DSN-MUI No. 117/DSN-MUI/II/2018 mengenai Layanan Pembiayaan Berbasis Teknologi Informasi Berdasarkan Prinsip Syariah menjadi dasar pelaksanaan fintech syariah. Fatwa tersebut menerangkan tentang pemanfaatan teknologi sebagai sarana layanan pembiayaan yang cepat, mudah, dan efisien (Nasional, 2018).

\section{Islamic Crowdfunding}

Islamic Crowdfunding merupakan sebuah kegiatan penggalangan dana atau crowdfunding yang dijalankan pada platform online yang menghubungkan antara investor sebagai pemilik dana dengan konsumen yang sedang membutuhkan pendanaan dengan syarat dana yang diberikan harus dipergunakan pada bisnis yang halal yang sesuai dengan syariat islam (Bahauddin, 2019). Pada islamic crowdfunding selain penggunaan dana yang harus sesuai dengan syariat islam, sumber dana yang 
digunakan untuk pendanaan juga harus halal dan jelas sumbernya. Oleh karena itu diperlukan peran Dewan Pengawas Syariah (DPS) untuk melakukan pengawasan terhadap kegiatan bisnis yang berbasis syariah seperti pada islamic crowdfunding sehingga dana yang digunakan dapat dijamin kehalalanya (Novitarani \& Setyowati, 2018).

Awal mula kemunculan crowdfunding yang berbasis syariah adalah ketika Ethics pte didirikan pada maret 2014. Ethis pte merupakan perusahaan startup yang berasal dari singapura yang telah menghasilkan dana lebih dari Rp.24,2 miliar rupiah melalui penggalangan dana yang digunakan untuk pembelian rumah baru dengan harga terjangkau di Indonesia.

Perkembangan startup crowdfunding pada beberapa tahun belakangan mengalami peningkatan yang sangat pesat, bukti perkembanganya adalah munculnya inovasi baru yaitu penawaran saham yang disebut equity crowdfunding. Otoritas Jasa Keuangan (OJK) saat ini tengah menyusun peraturan mengenai equity crowdfunding atau pengumpulan dana dengan sistem penawaran saham berbasis teknologi, hal ini dilakukan untuk mempermudah investor dan mendorong perkembangan crowdfunding. Pada aktivitas penawaran saham kepada pemodal, equity crowdfunding dijalankan secara online dengan memanfaatkan teknologi yang semakin canggih (Mollick 2014).

\section{METODE PENELITIAN}

Metode penelitian yang digunakan adalah metode penelitian kualitatif dengan pendekatan fenomonologi (Asih, 2015). Tujuan peneliti menggunakan pendekatan fenomonologi adalah untuk melihat fenomena secara apa adanya dengan mengamati pengalaman responden dalam berinvestasi. Jenis data pada penelitian ini adalah data primer, yang merupakan hasil dari wawancara yang dilakukan oleh peneliti kepada 40 responden yang bekerja sebagi karyawan swasta dan mahasiswa yang sudah pernah berinvestasi.

Prosedur pengumpulan data pada penelitian ini dilakukan dalam beberapa tahap, tahap pertama adalah menentukan 40 responden dengan teknik purposive dengan kriteria pernah melakukan kegiatan berinvestasi. Tahap kedua adalah menyusun panduan wawancara. Tahap ketiga adalah pengumpulan data yang dilakukan dengan wawancara. Prosedur analisa data dalam penelitian ini menggunakan bantuan aplikasi ATLAS.ti 8, dimana dalam aplikasi ini hasil wawancara akan diolah dan digolongkan menjadi beberapa codes yang sesuai dengan tujuan penelitian dan hasilnya berupa jaringan atau network yang akan dimuat dalam pembahasan penelitian ini. 


\section{HASIL PENELITIAN DAN PEMBAHASAN}

Proses analisis data pada penelitian ini menggunakan bantuan dari aplikasi ATLAS.ti 8 yang akan menghasilkan gambaran hasil penelitian berupa jaringan atau network yang menghubungkan hasil temuan dengan kategori-kategori yang ada. Data pada penelitian ini diperoleh dengan melakukan wawancara kepada investor terkait dengan pengalaman dalam berinvestasi, seperti manfaat berinvestasi, hambatan berinvestasi, dan ketertarikan dengan adanya teknologi baru dalam investasi.

Peneliti menggunakan teori UTAUT (Unifed Teory of Acceptance and Use of Technology) atau Teori Terpadu Penerimaan dan Penggunaan Teknologi yang terbagi menjadi 4 kategori yaitu Perfomance Expectancy, Effort Expectancy, Social Influence, dan Facilitating Conditions. Ke empat kategori yang yang dimaksud dapat dilihat pada gambar bagan berikut ini:

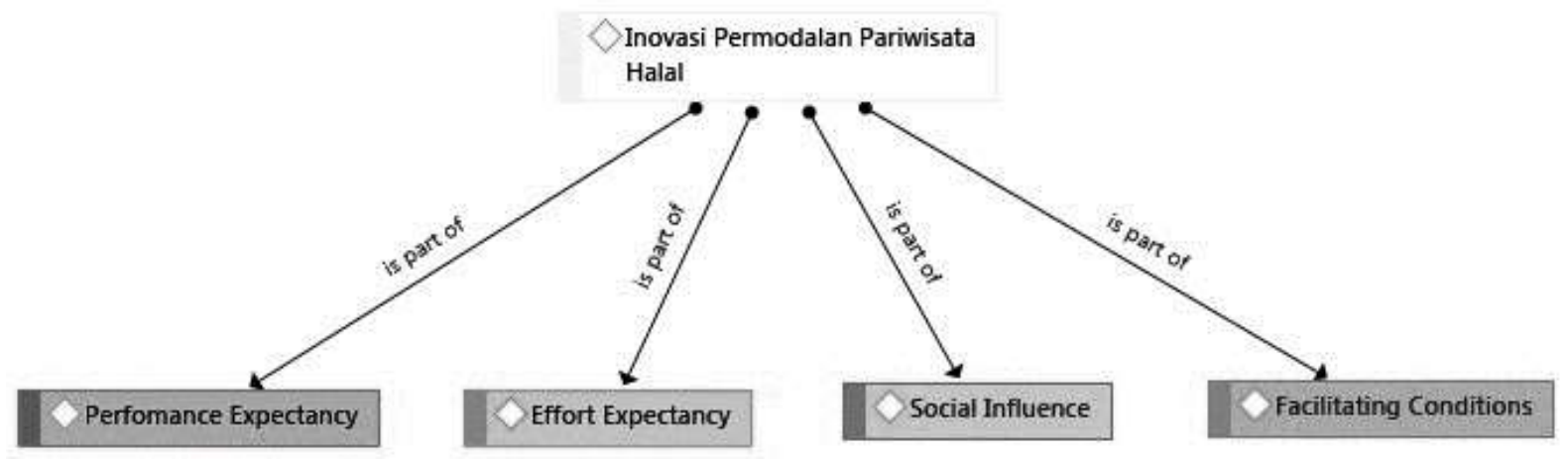

Gambar 1 Kategori Hasil Penelitian

\section{Perfomance Expectancy}

Pada sebuah fintech syariah dapat menerapkan Islamic Crowdfunding di dalamnya, dengan tetap memperhatikan aturan-aturan islam dalam menawarkan proyek dan produk (Wahjono et al, 2015). Uang yang akan digunakan sebagai permodalan sebuah proyek juga harus halal dan jelas sumbernya, sehingga diperlukan adanya pihak yang dapat melakukan pengawasan dan menjamin kehalalan uang yang digunakan untuk membiayai proyek dan produk yaitu Dewan Pengawas Syariah (DSN). Jika ada investor yang ingin menginvestasikan dananya maka harus menandatangani formulir yang menyatakan jika uang yang akan diinvestasikan adalah uang yang halal. Skema dari inovasi permodalan pariwisata halal ini dapat dilihat pada bagan berikut ini. 


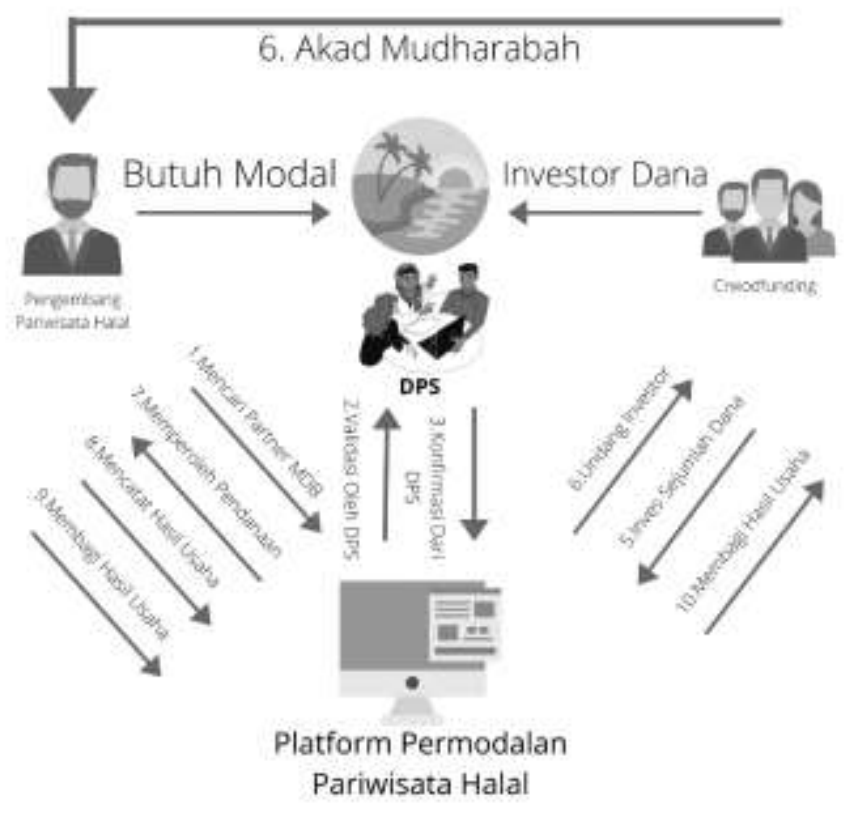

\section{Gambar 2 Skema Inovasi Permodalan Pariwisata Halal}

Keterbatasan dana yang dianggarkan oleh pemerintah untuk pengembangan pariwisata halal di Indonesia menjadi sebuah masalah yang harus segera diselesaikan. Salah satu solusi yang bisa digunakan adalah dengan membuat sebuah platform untuk permodalan pengembangan pariwisata halal di Indonesia. Platform ini dijalankan secara online dengan memanfaatkan perkembangan teknologi pada sektor keuangan yaitu fintech syariah, dan fokus dalam kegiatanya adalah untuk memberikan pendanaan kepada pihak pengembang pariwisata halal di Indonesia. Melalui platform ini juga pihak pengembang pariwisata halal yang mengalami kesulitan dalam hal permodalan dapat dipertemukan dengan pihak yang ingin berinvestasi.

Hasil wawancara kepada 40 responden menyatakan bahwa 95\% responden setuju dan mendukung adanya inovasi platform permodalan untuk pariwisata halal, karena menurut mereka dengan adanya platform tersebut akan memberikan banyak manfaat, sedangkan $5 \%$ responden menyatakan tidak setuju dengan adanya platform permodalan tersebut, mereka menilai sektor pariwisata masih belum menjanjikan untuk berinvestasi.

Kategori pertama pada penelitian ini yaitu perfomance expectancy yang dilihat dari tingkat ketertarikan responden terhadap platform permodalan pariwisata halal dari segi manfaat yang didapat. Hasil dari kategori perfomance expectancy tersaji dalam bentuk bagan atau network berikut ini. 


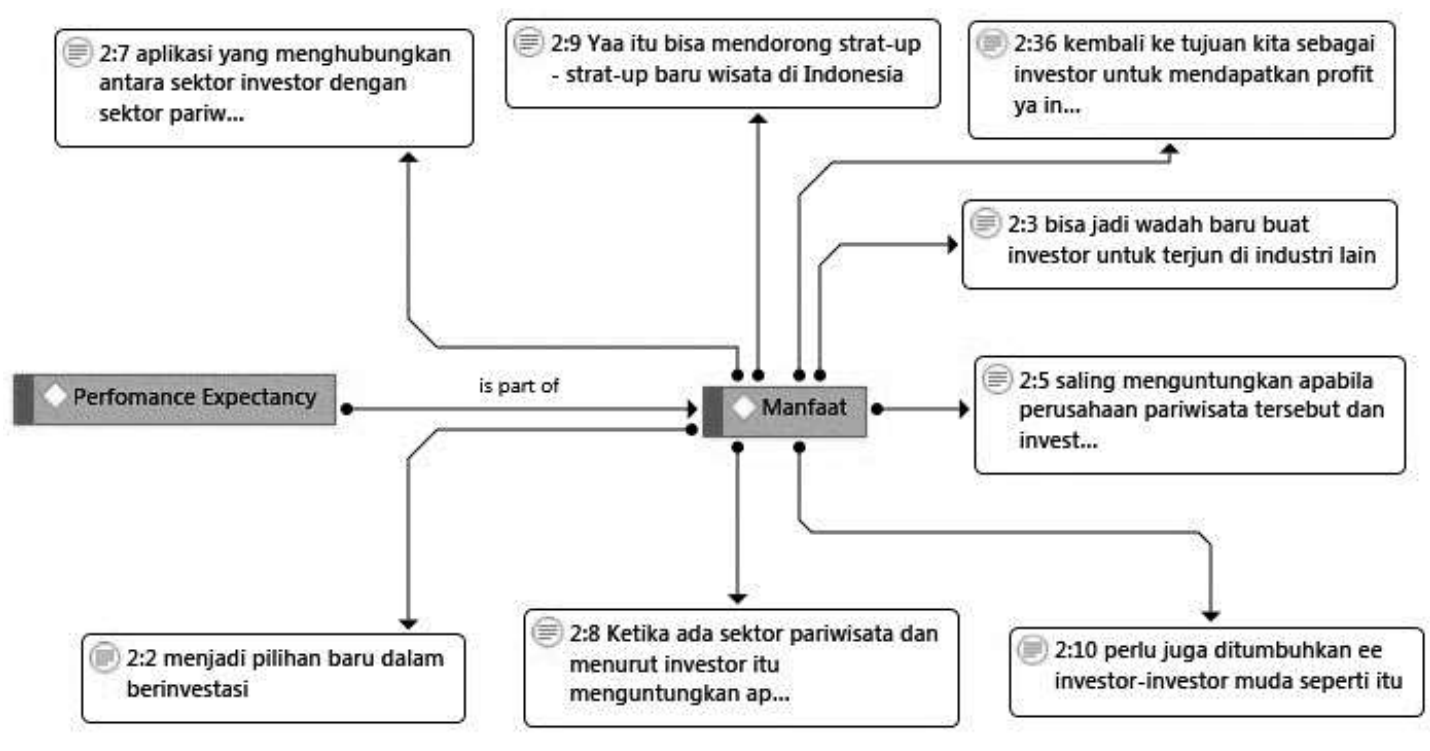

Gambar 3 Hasil Network Perfomance Expectancy

Pertama menghubungkan antara pihak investor dengan pihak pengembang pariwisata halal (gambar 2:7). Sejauh ini masih belum ada platform permodalan yang berfokus pada sektor pariwisata halal, sehingga para responden berpendapat dengan adanya inovasi platform permodalan untuk pariwisata halal ini pihak investor menjadi lebih mudah dalam mengembangkan dananya, dan pihak pengembang pariwisata mendapat modal untuk mengembangkan pariwisatanya.

Kedua menjadi wadah baru bagi investor untuk menginvestasikan dananya yaitu pada sektor pariwisata (gambar 2:3). Menurut responden dengan adanya inovasi platform permodalan untuk pariwisata halal ini membuat kegiatan investasi menjadi lebih beragam. Mengingat sektor pariwisata di Indonesia memiliki potensi yang besar sehingga dapat menarik minat para investor untuk menginvestasikan dananya pada sektor pariwisata.

Ketiga membantu investor untuk mencapai tujuan berinvestasi yaitu mendapatkan profit atau keuntungan (gambar 2:36). Tujuan awal seseorang dalam berinvestasi adalah untuk mendapatkan return atau keuntungan. Menurut responden dengan adanya inovasi platform permodalan pariwisata halal ini akan memberikan keuntungan yang besar kepada para investor, karena potensi pariwisata di Indonesia sangat besar terutama pariwisata halal yang masih terus dikembangkan.

Ke-empat saling memberikan keuntungan bagi kedua pihak yaitu investor dan pengembang pariwisata (gambar 2:5). Menurut responden dengan adanya inovasi platform permodalan untuk pariwisata halal ini akan memberikan keuntungan bagi semua pihak. Pihak investor dana bisa mendapatkan keuntungan yang besar mengingat potensi pariwisata halal di Indonesia yang besar, serta pihak pengembang pariwisata halal juga akan mendapat keuntungan berupa tambahan modal untuk mengembangkan fasilitas dan infrastruktur agar dapat menarik minat wisatawan untuk berkunjung. 
Hasil dari network perfomance expectancy diatas di dukung oleh hasil penelitian yang dilakukan oleh Lilik Rahwati, dimana dalam penelitiannya menyatakan bahwa dengan adanya fintech yang berbasis syariah akan banyak memberikan manfaat bagi konsumen seperti dalam mendapatkan modal dan mencari keuntungan(Rahmawati et al., 2020).

\section{Effort Expectancy}

Pada kategori kedua Effort Expectancy ini peneliti melihat dari sudut pandang kemudahan dalam penggunaan platform permodalan ini. Hasil dari wawancara kepada 40 responden yang sebagian besar masih berprofesi sebagai mahasiswa dan sisanya sebagai karyawan swasta, menyatakan jika kemauan mereka untuk berinvestasi dipengaruhi oleh profesi yang dijalani, dengan faktor teknologi sebagai pendukung. Selain itu faktor latar belakang pendidikan menjadi pertimbangan mereka dalam berinvestasi.

Sebagai contoh adalah $75 \%$ dari keseluruhan total responden yang diwawancarai berprofesi sebagai mahasiswa, dimana alasan awal mereka berinvestasi adalah untuk memenuhi kewajiban pada mata kuliah investasi yang mengharuskan mereka untuk berinvestasi, sedangkan 25\% sisanya berprofesi sebagai karyawan swasta, dimana alasan mereka berinvestasi adalah ingin mencari penghasilan tambahan. Para responden menilai keberadaan teknologi ini sangat penting, karena dapat mempermudah dalam berinvestasi serta mereka dapat dengan mudah untuk memantau perkembangan investasi mereka kapan saja dan dimana saja. Hasil dari kategori Effort Expectancy tersaji dalam bentuk bagan atau network berikut ini.

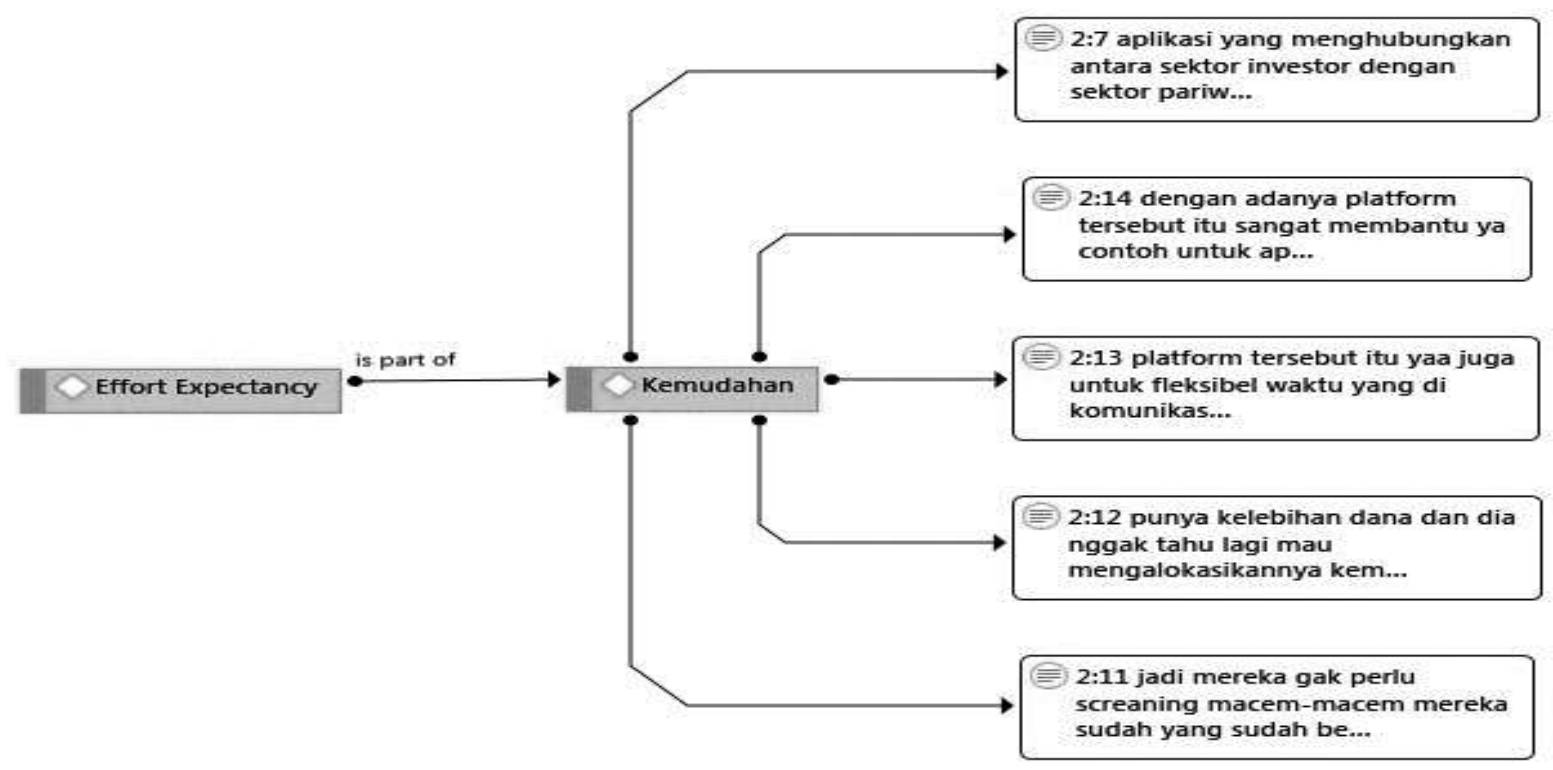

Gambar 4 Hasil Network Effort Expectancy 
Pertama menjadi pilihan bagi investor maupun masyarakat yang mempunyai kelebihan dana namun kesulitan dalam mengalokasikanya (gambar 2:12). Menurut responden dengan adanya inovasi platform permodalan pariwisata halal ini memberikan kemudahan bagi investor maupun masyarakat yang memiliki kelebihan dana namun kesulitan dalam mengalokasikanya, sehingga mereka dapat menginvestasikan dananya pada platform permodalan pariwisata halal ini.

Kedua memudahkan investor karena tidak memerlukan screening yang mendalam (gambar 2:11). Menurut responden dalam inovasi platform permodalan untuk pariwisata halal ini nantinya tidak memerlukan screening yang mendalam, karena ketika investor mengingat besarnya potensi pariwisata yang ada di Indonesia maka akan membuat mereka tertarik untuk berinvestasi di sektor pariwisata.

Ketiga menghubungkan antara pihak investor dana dengan pihak pengembang pariwisata (gambar 2:7). Menurut responden dengan adanya inovasi platform permodalan untuk pariwisata ini akan memberikan kemudahan bagi pihak pengembang pariwisata yang kekurangan anggaran dalam mengembangkan pariwisata, karena dengan memanfaatkan platform ini pihak pengembang pariwisata dapat berhubungan dengan pihak investor yang ingin menginvestasikan dananya di sektor pariwisata halal.

Ke-empat memberikan kemudahan yaitu fleksibel dalam waktu penggunaan (gambar 2:13). Para responden menyatakan dengan menggunakan teknologi dalam berinvestasi akan mempermudah mereka dalam hal waktu penggunaan yang fleksibel. Latar belakang profesi para responden yang sebagian besar adalah mahasiswa dan karyawan swasta, menjadikan kegiatan investasi bukan menjadi prioritas melainkan hanya sebagai kegiatan sampingan untuk mendapatkan keuntungan pasif.

Pada penelitian mengenai pengembangan produk perbankan syariah mengemukakan bahwa dengan munculnya financial technology memberikan kemudahan bagi para konsumen. Seperti dalam bertransaksi, investasi, dan juga pengumpulan dana. Hal tersebut senada dengan hasil dari network effort expectancy di atas(Rasyid et al, 2017).

\section{Social Influence}

Pada kategori ketiga Social Influence ini peneliti melihat dari sudut pandang ketertarikan dan minat investor dalam berinvestasi pada inovasi platform permodalan pariwisata halal. Keseluruhan total responden yang telah diwawancarai ada 7,5\% responden yang beragama non islam, namun hal tersebut tidak mempengaruhi minat mereka untuk berinvestasi, karena tujuan dari investasi sendiri adalah untuk mendapatkan keuntungan. Hasil dari kategori Social Influence tersaji dalam bentuk bagan atau network berikut ini. 


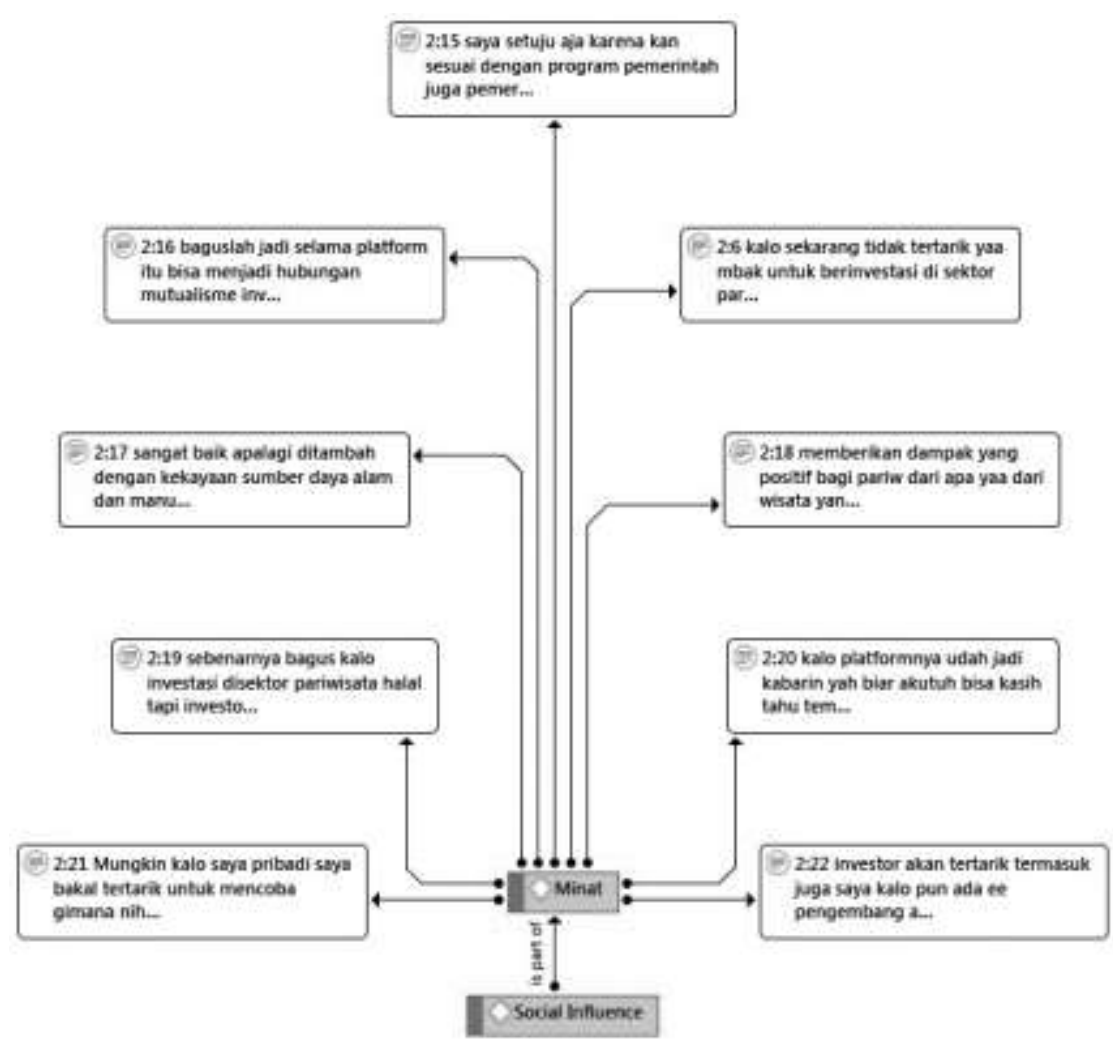

Gambar 5 Hasil Network Social Influence

Pertama tertarik untuk mencoba platform permodalan pariwisata halal ini (gambar 2:21). Mereka menyebutkan ingin mencoba untuk mengetahui bagaimana sistem pada platform permodalan ini, serta bagaimana return dan hasil yang akan mereka dapatkan jika berinvestasi pada platform permodalan untuk pariwisata halal ini. Menurut mereka akan banyak investor yang akan tertarik untuk berinvestasi pada platform ini nantinya.

Kedua menjadi hubungan mutualisme antara semua pihak yang terlibat (gambar 2:16). Menurut responden dengan adanya inovasi platform permodalan untuk pariwisata halal tersebut akan menciptakan hubungan mutualisme atau hubungan yang saling menguntungan antara semua pihak yang terlibat, sehingga hal tersebut akan menarik minat pihak investor maupun pengembang pariwisata untuk menggunakan platform tersebut.

Ketiga secara tidak langsung platform ini akan mendukung program pemerintah dalam pengembangan sektor pariwisata khususnya pariwisata halal di Indonesia (gambar 2:15). Para responden menyatakan berminat untuk menggunakan dan berinvestasi pada platform permodalan pariwisata halal tersebut, karena secara tidak langsung kegiatan pada platform tersebut mendukung program pemerintah dalam pengembangan pariwisata halal di Indonesia.

Ke empat di dukung oleh kekayaan sumber daya alam dan manusia yang memadai (gambar 2:17). Menurut responden dengan adanya sumber daya alam yang besar dan sumber daya manusia yang semakin memadai serta didukung teknologi 
yang semakin canggih, akan mendukung platform permodalan untuk pariwisata halal ini dan menarik minat investor untuk menginvestasikan dana mereka pada sektor pariwisata.

Hasil penelitian yang dilakukan oleh Hendri Adinugraha pada tahun 2018 tentang desa wisata halal dapat mendukung hasil dari network social influence pada penelitian ini, Hendri mengungkapkan bahwa potensi sumber daya alam dan kesesuaian dengan program pemerintah menjadi daya tarik terhadap minat konsumen (Adinugraha et al., 2018).

\section{Facilitating Conditions}

Kategori keempat pada penelitian ini yaitu Facilitating Conditions dilihat dari tingkat kualitas infrastruktur sistem yang mendukung penggunaan platform melalui saran perbaikan dari para responden. Hasil wawancara kepada responden menyatakan 95\% responden memberikan saran dan kritik yang mendukung pengembangan platform ini, sedangkan $5 \%$ responden tidak memberikan saran. Hasil dari kategori Facilitating Conditions tersaji dalam bentuk bagan atau network berikut ini.

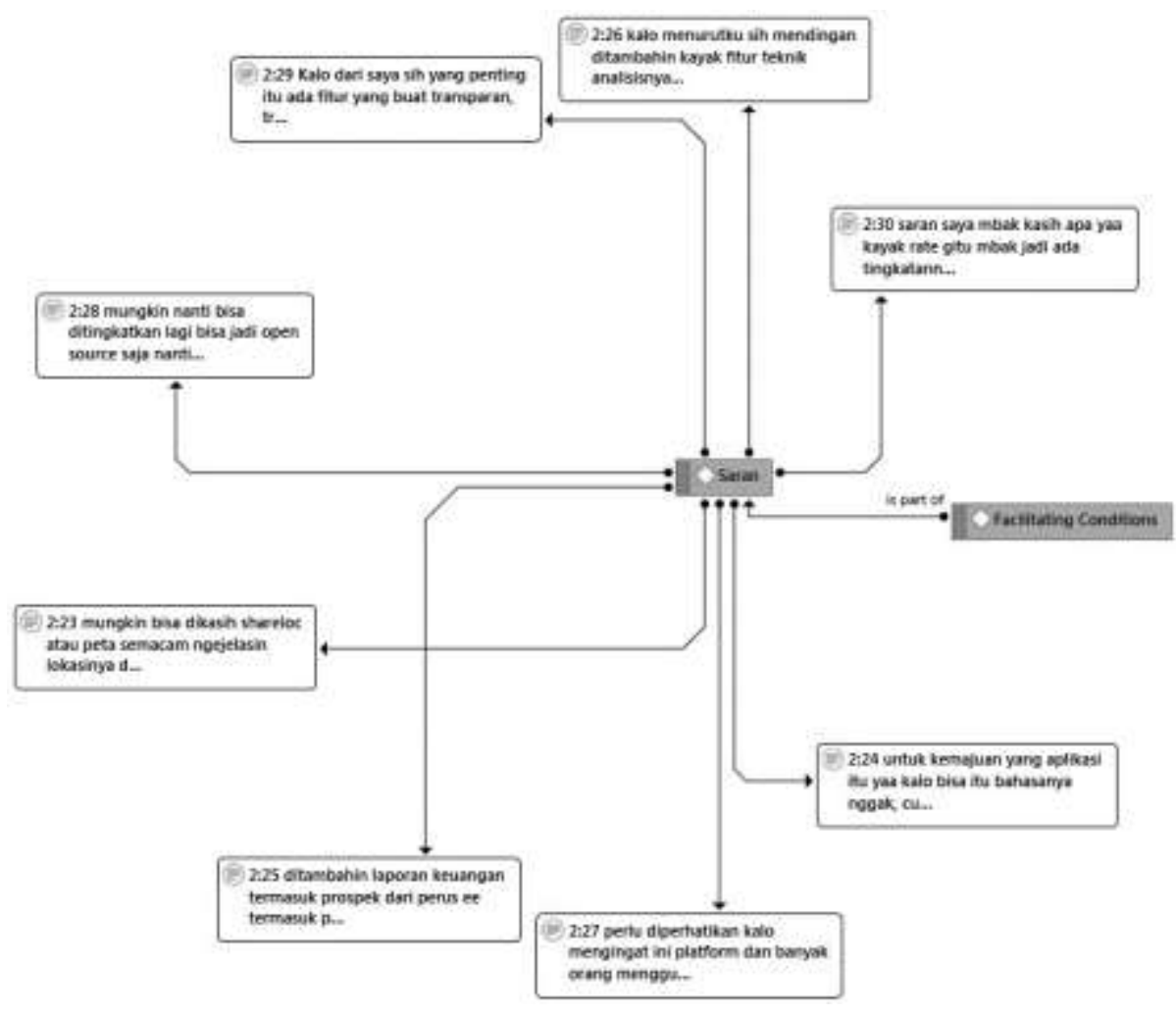

\section{Gambar 6 Hasil Network Facilitating Conditions}

Pertama perlu adanya legalitas dari pihak yang berwenang mengenai pendirian platform permodalan (gambar 2:27). Menurut responden status kelegalan suatu platform permodalan menjadi bahan pertimbangan utama investor sebelum berinvestasi mengingat banyaknya kasus penipuan tentang platform permodalan, 
sehingga penting untuk sebuah platform permodalan memiliki legalitas dari badan yang berwenang agar para investor menjadi percaya dan berani untuk berinvestasi pada platform tersebut.

Kedua perlu adanya fitur share location, sebagian responden menyarankan agar pada inovasi platform permodalan pariwisata halal ditambahkan fitur share location (gambar 2:23). Menurut responden fitur tersebut penting, agar para investor dapat mengetahui lokasi pariwisata yang akan didanai dan agar para investor lebih yakin dan percaya kepada platform permodalan untuk pariwisata halal ini, serta untuk menghindari tindak penipuan.

Ketiga perlu penambahan teknik analisis, menurut responden teknik analisis perlu ditambah pada inovasi platform permodalan pariwisata halal tersebut (gambar 2:26). Menurut responden adanya teknik analisis akan membantu para investor dalam mengambil keputusan untuk berinvestasi, serta membantu para investor muda dalam berinvestasi pada sektor pariwisata halal.

Keempat perlu penambahan laporan keuangan, dalam sebuah investasi laporan keuangan menjadi sebuah kewajiban yang harus dipenuhi oleh pihak penyedia layanan platform permodalan kepada para investor dana (gambar 2:25). Menurut responden dengan adanya penambahan laporan keuangan pada platform permodalan pariwisata halal tersebut akan membantu pihak investor dalam mengetahui penggunaan dana yang telah mereka investasikan.

Hasil penelitiannya tentang pariwisata halal, mengungkapkan bahwa dalam pengembangan pariwisata halal perlu adanya peningkatan infrastruktur dan fasilitas yang mendukung. Hal tersebut senada dengan hasil network facilitating conditions pada penelitian ini, dimana dalam platform permodalan pariwisata diatas masih membutuhkan adanya peningkatan pada infrastruktur dan fasilitas yang mendukung, agar platform dapat berjalan dengan maksimal (Satriana \& Faridah, 2018).

\section{KESIMPULAN}

Kesimpulan dari penelitian ini adalah sebagian besar responden setuju dengan adanya rencana pembangunan platform permodalan pariwisata halal. Para responden menyebutkan dengan adanya platform permodalan pariwisata halal akan memberikan banyak kemudahan bagi banyak pihak. Selain karena faktor kemudahan dalam penggunaan, responden juga tertarik untuk berinvestasi pada platform tersebut karena memberikan banyak manfaat yaitu mendukung program pemerintah dalam pengembangan pariwisata halal di Indonesia. Saran dari para responden agar proses pengembangan pariwisata halal di Indonesia berjalan dengan baik adalah dengan meningkatkan fasilitas dan infrastruktur agar dapat menarik lebih banyak wisatawan. 


\section{DAFTAR PUSTAKA}

Adinugraha, H. H., Sartika, M., \& Kadarningsih, A. (2018). Desa Wisata Halal : Konsep dan Implementasinya Di Indonesia. Human Falah, 5(1), 28-48.

Ansori, M. (2019). Perkembangan dan Dampak Financial Technology (Fintech) terhadap Industri Keuangan Syariah di Jawa Tengah. Wahana Islamika: Jurnal Studi Keislaman, 5(1), 31-45.

Asih, I. D. (2015). Fenomenologi Husserlsebuah Cara “Kembali Ke Fenomena."

Bahauddin, A. (2019). Aplikasi Blockchain dan Smart Contract Untuk Mendukung Supply Chain Finance Umkm Berbasis Crowdfunding Syariah. Journal Industrial Servicess, 5(1), 107-111. https://doi.org/10.36055/jiss.v5i1.6511

CrescentRating. (2018). Global Muslim Travel Index 2018. https://www.crescentrating.com/reports/mastercard-crescentrating-globalmuslim-travel-index-gmti-2018.html

Hendratmi, A., Sukmaningrum, P. S., Ryandono, M. N. H., \& Ratnasari, R. T. (2019). The Role of Islamic Crowdfunding Mechanisms in Business and Business Development. Journal of Business and Economics Review, 4(1), 10-23. www.gatrenterprise.com/GATRJournals/index.html

Hoque, N., Hasmat Ali, M., Arefeen, S., Masrurul Mowla, M., \& Mamun, A. (2018). Use of Crowdfunding for Developing Social Enterprises: An Islamic Approach. International Journal of Business and Management, 13(6), 156. https://doi.org/10.5539/ijbm.v13n6p156

IMTI. (2018). Indonesia Muslim Travel Index (IMTI) 2018.

Indonesia.go.id. (2019). Berapa Jumlah Penduduk Muslim Indonesia. https://www.indonesia.go.id/profil/agama

Jaelani, A. (2017). Halal Tourism Industry in Indonesia: Potential and Prospects. SSRN Electronic Journal. https:/ / doi.org/10.2139/ssrn.2899864

Marginingsih, R. (2019). Analisis SWOT Technology Financial (FinTech) Terhadap Industri Perbankan. Cakrawala - Jurnal Humaniora, 19(1), 55-60. https://doi.org/10.31294/jc.v19i1.4893

Mollick, E. (2014). The dynamics of crowdfunding: An exploratory study. Journal of Business Venturing, 29(1), 1-16. https:/ / doi.org/10.1016/j.jbusvent.2013.06.005

Nasional, D. S. (2018). Layanan Pembiayaan Berbasis Teknologi Informasi Berdasarkan Prinsip Syariah - DSN-MUI. https://dsnmui.or.id/layanan-pembiayaanberbasis-teknologi-informasi-berdasarkan-prinsip-syariah/ 
Ricky: Capital; halal tourism; crowdfunding

Novitarani, A., \& Setyowati, R. (2018). Analisis Crowdfunding Syariah Berdasarkan Prinsip Syariah Compliance Serta Implementasinya Dalam Produk Perbankan Syariah. Jurnal Kajian Hukum Islam, 12, 249.

OJK. (2019). Perusahaan Fintech Lending Berizin Per Februari 2019.

Rahmawati, L., Rahayu, D. D., Nivanty, H., \& Lutfiah, W. (2020). Fintech Syariah: Manfaat dan Problematika Penerapan Pada UMKM. Jurnal Masharif Al-Syariah: Jurnal Ekonomi Dan Perbankan Syariah, 5(1), 75-90.

Rasyid, M. A.-Z., Setyowati, R., \& Islamiyati. (2017). Crowdfunding Syariah Untuk Pengembangan Produk Perbankan Syariah Dari Perspektif Shariah Compliance. 6(4), 116.

Satriana, E. D., \& Faridah, H. D. (2018). Halal Tourism: Development, Chance And Challenge. Journal of Halal Product and Research, 1(2), 32. https://doi.org/10.20473/jhpr.vol.1-issue.2.32-43

Wahjono, S. I., Marina, A., \& Widayat. (2015). Islamic Crowdfunding: Alternative Funding Solution. Jurnal Prosiding.

Wahyuni, R. A. E. (2019). Perkembangan Ekonomi Islam Di Indonesia Melalui Penyelenggaraan Fintech Syariah. Mahkamah, 4(2), 184-192.

Zuhro, F. (2019). Pengembangan Ekonomi Syariah terhadap Potensi Pariwisata Besar oleh Bank Indonesia. Islamic Banking: Jurnal Pemikiran Dan Pengembangan Perbankan Syariah, 5(1), 65-80. https:/ / doi.org/10.36908/isbank.v5i1.70 
